feed composition. 3rd rev. National Academy Press, Washington, DC.

Robertson, J.B., and P.J. Van Soest. 1981. The detergent system of analysis and its application to human food. p. 123-158. In W.P.T. James and $\mathrm{O}$. Theander (ed.) The analysis of dietary fiber in foods. Marcel Dekker, New York.

Rodríguez, C.A., J. González, M.R. Alvir, and C. Cajarville. 1999. Underestimation of in situ effective degradability of $\mathrm{N}$ due to microbial contamination. p. 67. In G.E. Lobley et al. (ed.) 8th Int. Symp. on Prot. Met. and Nutr., Aberdeen. 1-4 Sept. 1999. Wageningen Pers., the Netherlands.

Sniffen, C.J., J.D. O’Connor, P.J. Van Soest, D.G. Fox, and J.B. Russell. 1992. A net carbohydrate and protein system for evaluating cattle diets: II Carbohydrate and protein availability. J. Anim. Sci. 70:3562-3577.
Traxler, M.J., D.G. Fox, P.J. Van Soest, A.N. Pell, C.E. Lascano, D.P.D. Lanna, J.E. Moore, R.P. Lana, M. Vélez, and A. Flores. 1998. Predicting forage indigestible NDF from lignin concentration. J. Anim. Sci. 76:1469-1480.

Van Soest, P.J. 1994. Nutritional ecology of the ruminant. 2nd ed. Cornell Univ. Press, Ithaca, NY.

Van Soest, P.J., J.B. Robertson, and B.A. Lewis. 1991. Methods for dietary fiber, neutral detergent fiber, and nonstarch polysaccharides in relation to animal nutrition. J. Dairy Sci. 74:3583-3597.

White, B.A., R.J. Mackie, and K.C. Doerner. 1993. Enzymatic hydrolysis of forage cell walls. p. 465-484. In H.G. Jung et al. (ed.) Forage cell wall structure and digestibility. ASA, CSSA, and SSSA, Madison, WI.

Yemm, E.W., and A.U. Willis. 1954. The estimation of carbohydrates in plant extracts by anthrone. Biochem. J. 57:508-514.

\title{
Performance of 15 Miscanthus Genotypes at Five Sites in Europe
}

\author{
John C. Clifton-Brown,* Iris Lewandowski, Bengt Andersson, Gottlieb Basch, Dudley G. Christian, \\ Jens Bonderup Kjeldsen, Uffe Jørgensen, Jørgen V. Mortensen, Andrew B. Riche, \\ Kai-Uwe Schwarz, Koeyumars Tayebi, and Fernando Teixeira
}

\begin{abstract}
Miscanthus is a genus of high-yielding perennial rhizomatous grasses with $\mathrm{C}_{4}$ photosynthesis. Extensive field trials of Miscanthus spp. biomass production in Europe during the past decade have shown several limitations of the most widely planted clone, $M . \times$ giganteus Greef et Deu. A 3-yr study was conducted at five sites in Europe (Sweden, Denmark, England, Germany, and Portugal) to evaluate adaptation and biomass production potential of four acquisitions of $M . \times$ giganteus (No. 1-4) and 11 other genotypes, including $M$. sacchariflorus (Maxim.) Benth. (No. 5), M. sinensis Andersson (No. 11-15), and hybrids (No. 6-10). At each site, three randomized blocks containing a 5- by 5-m plot of each genotype were established (except in Portugal where there were two blocks) with micropropagated plants at 2 plants $\mathrm{m}^{-2}$. In Sweden and Denmark, only M. sinensis and its hybrids satisfactorily survived the first winter following planting. Mean annual yields across all sites for all surviving genotypes increased each year from $2 \mathrm{t} \mathrm{ha}^{-1}$ dry matter following the first year of growth to 9 and $18 \mathrm{t} \mathrm{ha}^{-1}$ following the second and third year, respectively. Highest autumn yields at sites in Sweden, Denmark, England, and Germany were 24.7 ( $M$. sinensis hybrid no. 8), 18.2 (M. sinensis hybrid no. 10), $18.7\left(M . \times\right.$ giganteus no. 3), and $29.1 \mathrm{t} \mathrm{ha}^{-1}(M . \times$ giganteus no. 4$)$, respectively. In Portugal, where irrigation was used, the top-yielding genotype produced $40.9 \mathrm{t} \mathrm{ha}^{-1}$ dry matter (M. sinensis hybrid no. 7). Highest-yielding genotypes in Sweden and Denmark were among the lowest yielding in Portugal and Germany, demonstrating strong genotype $\times$ environment interactions.
\end{abstract}

$\mathrm{M}$ ISCANTHUS $\times$ giganteus was introduced to Europe in the 1930s by Aksel Olsen and was observed

J.C. Clifton-Brown and I. Lewandowski, Univ. of Hohenheim, Inst. for Crop Prod. and Grassl. Res. (340), D-70599 Stuttgart, Germany; B. Andersson, Svalöf Weibull, AB-S 268 81, Sweden; G. Basch, K. Tayebi, and F. Teixeira, Departamento de Fitotecnica, Universidade de Évora, Herdade da Mitra, P-7001 Evora/Codex, Portugal; D.G. Christian and A.B. Riche, Rothamsted Exp. Stn., Harpenden, Hertfordshire AL5 2JQ, United Kingdom; and J. Bonderup Kjeldsen, U. Jørgensen, J.V. Mortensen, and K.-U. Schwarz, Danish Inst. of Agric. Sci., Dep. of Soil Sci., Res. Cent. Foulum, P.O. Box 50, 8830 Tjele, Denmark. Current address of J.C. Clifton-Brown: Bot. Dep., Univ. of Dublin, Trinity College, Dublin 2, Ireland. This work was funded by the EU Contract no. FAIR3 CT-96-1392. Received 6 Oct. 2000. *Corresponding author (jcbrown@tcd.ie)

Published in Agron. J. 93:1013-1019 (2001). to have exceptionally vigorous growth (Linde-Laursen, 1993). In the late 1980s, interest in $\mathrm{C}_{4}$ perennial rhizomatous grasses, such as Miscanthus spp. (Nielsen, 1987), switchgrass (Panicum virgatum L.) (Christian, 1994), Cyperus spp., and Spartina spp. (Potter et al., 1995), for biofuel production increased due to their high yield potential and rising energy prices. Since 1983, extensive field trials of $M . \times$ giganteus have been carried out in northern Europe, showing the capacity of this genotype for yields $>20$ t dry matter ha $^{-1}$ year $^{-1}$ (Nielsen, 1987; Schwarz et al., 1994).

There are several reasons why European-wide biomass production from a single genotype within the Miscanthus genus is inadequate. First, in northern Europe, a number of sites established with $M . \times$ giganteus failed to survive during the first winter (Jones and Walsh, 2001), principally due to insufficient freeze tolerance of the overwintering rhizome. Second, it is unlikely that one single clone is sufficient to fulfil all of the quality requirements of different uses (combustion and fiber). Third, M. $\times$ giganteus, being a sterile triploid (Greef and Deuter, 1993), must be propagated vegetatively, either with rhizome cuttings or by micropropagation, making establishment expensive compared with crops established from seed. Fourth, growing large areas of a single clone increases disease risk. A broad genetic base and the provision of different Miscanthus genotypes are required to overcome these limitations.

As part of the European Miscanthus Improvement Project, a Miscanthus gene pool was created by combining collections directly from Asia and material already made available in Europe by German, Danish, and Swedish breeders. M. sinensis is characterized by a tuft-forming rhizome with high shoot densities while $M$. sacchariflorus is characterized by a broad, creeping rhizome with thick tall stems. $M . \times$ giganteus shows an intermediate type of rhizome between $M$. sinensis and $M$. sacchariflorus and is most probably a natural hybrid of the two (Greef and Deuter, 1993; Hodkinson et al., 1997).

In this paper, we report on field trials planted with 15 Miscanthus genotypes, which can be broadly divided 
Table 1. Miscanthus genotypes used in field trials, showing the European Miscanthus Improvement project (EMI) number, genotype name, genotype group abbreviation, ploidy, and acquisition details.

\begin{tabular}{|c|c|c|c|c|c|c|}
\hline EMI no. & Name & Group & Ploidy & Acquisition code & Acquired from & Additional Information \\
\hline $\mathbf{1}$ & M. $\times$ giganteus & Gig & 3n & LASEI1 & Larsen, Denmark & No. 16.05 in Greef et al., 1997 \\
\hline 2 & M. $\times$ giganteus & Gig & 3n & ILP53 & Knoblauch, Hornum & No. 16.21 in Greef et al., 1997 \\
\hline 3 & M. $\times$ giganteus & Gig & $3 n$ & HAGA 56 & Hagemann, Berlin & No. 17.02 in Greef et al., 1997 \\
\hline 4 & M. $\times$ giganteus & Gig & 3n & GREIF63 & Greifswald Bot. Gnd. & No. 17.03 in Greef et al., 1997 \\
\hline 5 & M. sacchariflorus & Sac & $4 n$ & MATEREC11 & Deuter, Germany & Matumura et al., 1985 \\
\hline 6 & M. sinensis Hybrid & Sin-H & 3n & GOFAL7 & Deuter, Germany & Hybrid selected in a $M$. sinensis popula \\
\hline 7 & M. sinensis Hybrid & Sin-H & $2 n$ & BERBO42 & Deuter, Germany & Hybrid of two $M$. sinensis \\
\hline 8 & M. sinensis Hybrid & Sin-H & aneuploid & RH43 & Deuter, Germany & Hybrid of $M$. sacchariflorus $\times M$. sinensis \\
\hline 9 & M. sinensis Hybrid & Sin-H & $2 n$ & JESEL78 & Deuter, Germany & Hybrid of two $M$. sinensis \\
\hline 10 & M. sinensis Hybrid & Sin-H & 2n & RH81 & Deuter, Germany & Hybrid of $M$. sacchariflorus $\times M$. sinensis \\
\hline 11 & M. sinensis & Sin & $2 n$ & 88-110 & Brander, Denmark & Collected in Honshu, Japan in 1983, selected 1988 \\
\hline 12 & M. sinensis & Sin & $2 n$ & 88-111 & Brander, Denmark & Collected in Honshu, Japan in 1983, selected 1988 \\
\hline 13 & M. sinensis & Sin & $2 n$ & $90-5$ & Brander, Denmark & Collected in Honshu, Japan in 1983, selected 1990 \\
\hline 14 & M. sinensis & Sin & $2 n$ & $90-6$ & Brander, Denmark & Collected in Honshu, Japan in 1983, selected 1990 \\
\hline 15 & M. sinensis & Sin & $2 n$ & SW217 & Andersson, Sweden & Collected Hokkaido, Japan in 1990 \\
\hline
\end{tabular}

into four genetic groups, at five locations: Sweden, Denmark, England, Germany, and Portugal. The objective was to screen these genotypes in different soil and climatic conditions for yield performance traits, including height, stem density, flowering time, autumn senescence rate, and yield. These measurements were used to identify the most suitable genotypes for the various regions of Europe and to improve our knowledge of the genetic base for the future development of Miscanthus spp. as a biomass crop.

\section{MATERIALS AND METHODS}

\section{Genotypes}

From the gene pool held by European breeders, 15 of the most promising genotypes were selected (Table 1). Four acquisitions of $M$. × giganteus genotypes (No. 1-4) were chosen because different crosses between $M$. sacchariflorus and $M$. sinensis were suspected to be in circulation all under the same name. Amplified fragment length polymorphism (AFLP) analysis had revealed small detectable differences between some of these acquisitions (Greef et al., 1997). One, M. sacchariflorus (No. 5), was selected from a collection described by Matumura et al. (1985). Five pure M. sinensis types were selected, four of which were collected by the Danish collector Poul Brander in 1983 on Honshu Island (No. 11-14) and one from central Hokkaido in 1990 by the Swedish collector Zandra Andersson (No. 15). Five Miscanthus spp. hybrids from crosses within $M$. sinensis and M. sacchariflorus (No. 6-10) were selected based on known differences in key physiological characteristics such as flowering time and autumn senescence time.

\section{Field Trials}

To ensure genetic and physiological uniformity at the five sites in Sweden, Denmark, England, Germany, and Portugal, all 15 genotypes were micropropagated by explants. Genotype no. $1-10$ were propagated by Martin Deuter at TINPLANT (Klein-Wanzleben, Germany), and Genotype no. 11-15 were propagated at the Danish Institute of Plant and Soil Science (Aarslev, Denmark). After in vitro multiplication, the plants were grown for 8 to $10 \mathrm{wk}$ in a temperate greenhouse in 5by $5-\mathrm{cm}$ peat pots before shipping to the field trials. Plant height at planting averaged $20 \mathrm{~cm}$.

At each site, three randomized blocks containing a 5- by 5-m plot of each genotype were established (except in Portugal where there were two blocks). Plantlets were planted by hand between March and June 1997 at a density of 2 plants $\mathrm{m}^{-2}$. Plots were irrigated after planting at all sites. In Portugal, irrigation was necessary throughout all growing seasons because of the limited rainfall during the growing season and sandy soils (Tables 2 and 3). Fertilizer was applied at rates equivalent to 60,44 , and $110 \mathrm{~kg} \mathrm{ha}^{-1} \mathrm{yr}^{-1} \mathrm{~N}, \mathrm{P}, \mathrm{K}$, respectively, which, combined with residual nutrients, was estimated to saturate crop requirements (Lewandowski et al., 2000). Mechanical weed control was used between transplanting and September in 1997.

Plant survival during the first winter was quantified by counting the number of plants producing new shoots in spring 1998, and percentages of the total plants planted in 1997 were calculated. Five plants were tagged for regular measurements at the beginning of each growing season on plants in predetermined positions at least two rows from the edge of each plot. Tagged plants were in the middle of the plots to avoid border effects. Stem density and canopy height were monitored regularly within the growing season on the tagged plants. In each

Table 2. Site locations, planting dates in 1997, soil textures (sand, silt, and clay), soil bulk densities (bulk), and soil types to subgroup level in five countries.

\begin{tabular}{|c|c|c|c|c|c|c|c|}
\hline \multirow[b]{2}{*}{ Country } & \multirow[b]{2}{*}{ Location } & \multirow[b]{2}{*}{ Planting date } & \multicolumn{5}{|c|}{ Soil characteristics $(0-90 \mathrm{~cm})$} \\
\hline & & & Sand & Silt & Clay & Bulk & Soil type $\dagger$ \\
\hline & & & & $-\%$ & - & $\mathrm{g} \mathrm{cm}^{-3}$ & \\
\hline Sweden & $55^{\circ} 60^{\prime} \mathrm{N}, \mathbf{1 4}^{\circ} 00^{\prime} \mathrm{E}$ & 17 June & 83.0 & 12.0 & 5.1 & 1.5 & Aeric Endoaquept \\
\hline Denmark & $56^{\circ} 30^{\prime} \mathrm{N}, 09^{\circ} 35^{\prime} \mathrm{E}$ & 03 June & 63.1 & 25.8 & 11.2 & 1.5 & Typic Fragiudalf \\
\hline England & $51^{\circ} 48^{\prime} \mathrm{N}, 00^{\circ} 21^{\prime} \mathrm{W}$ & 22 May & 41.5 & 29.2 & 29.4 & 1.7 & Aquic Paleudalf \\
\hline Germany & $48^{\circ} 40^{\prime} \mathrm{N}, 09^{\circ} 00^{\prime} \mathrm{E}$ & 21 May & 8.2 & 51.7 & 40.2 & 1.5 & Vertic Eutrudept \\
\hline Portugal & $38^{\circ} 43^{\prime} \mathrm{N}, 09^{\circ} 13^{\prime} \mathrm{W}$ & 21 Mar. & 76.2 & 15.7 & 8.1 & 1.6 & Aquic Xerofluvent \\
\hline
\end{tabular}

$\dagger$ Soil Survey Staff, 1999. 
Table 3. Mean air temperature and rainfall at the field sites in the five countries for the period April to September in 1997, 1998, and 1999; the long term (LT) mean for this period (>10 yr data during last $30 \mathrm{yr}$ ), and the annual LT (Ann.) mean.

\begin{tabular}{|c|c|c|c|c|c|c|c|c|c|c|}
\hline \multirow[b]{3}{*}{ Country } & \multicolumn{5}{|c|}{ Air temperature } & \multicolumn{5}{|c|}{ Rainfall } \\
\hline & \multicolumn{4}{|c|}{ April to September } & \multirow{2}{*}{$\underset{\text { mean }}{\text { Ann. LT }}$} & \multicolumn{4}{|c|}{ April to September } & \multirow{2}{*}{$\underset{\text { mean }}{\text { Ann. LT }}$} \\
\hline & 1997 & 1998 & 1999 & LT mean & & 1997 & 1998 & 1999 & LT mean & \\
\hline & & & 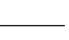 & 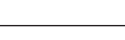 & 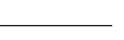 & & & - & & 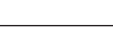 \\
\hline Sweden & 13.4 & 12.5 & 13.8 & 13.0 & 7.9 & 297 & 459 & 416 & 359 & 696 \\
\hline Denmark & 12.9 & 12.0 & 13.0 & 12.1 & 7.3 & 354 & 334 & 409 & 334 & 626 \\
\hline England & 14.2 & 13.6 & 14.4 & 12.9 & 9.1 & 273 & 436 & 364 & 319 & 688 \\
\hline Germany & 13.6 & 13.8 & 14.9 & 13.3 & 7.9 & 374 & 326 & 410 & 425 & 687 \\
\hline Portugal $\dagger$ & 23.0 & 21.4 & 20.2 & 19.6 & 15.4 & 327 & 197 & 147 & 156 & 665 \\
\hline
\end{tabular}

$\dagger$ In Portugal, irrigation between April and September was 300, 382, and 506 mm in 1997, 1998, and 1999, respectively.

autumn, greenness (an indication of the senescence) of the shoots was assessed on the tallest shoot of three of the tagged plants. If the length of the green part of a fully expanded leaf was $>60 \%$, then it was counted as green. If the green part was $<60 \%$, then it was counted as dead. Green leaf area was estimated by eye. Percentage greenness was calculated from the sum of green-scored leaves over the total number of leaves on a shoot $\times 100$. Three shoots per plot were pooled to make a plot mean, and plot means were used as replicates $(n=3$, except Portugal where $n=2$ ).

Each autumn, a sample of $2 \mathrm{~m}^{2}$ was harvested from within the central area of the plot (avoiding border effects) to assess the total aboveground productivity of each genotype. Cutting height for yield determinations was $5 \mathrm{~cm}$. Moisture content was measured by drying at $80^{\circ} \mathrm{C}$ until constant weight had been achieved, and dry matter yield was calculated as tonnes of dry matter per hectare.

\section{Statistical Analyses}

When data were normally distributed, analysis of variance (ANOVA) was used to determine significant differences. For comparisons of shoot density, plant height, and yield among genotypes within a country at a particular sampling time, a minimum significant difference was calculated by the Tukey procedure at $P=0.05$. Interactions among genotype, year, and country, where appropriate, are shown in the tables. For shoot greenness, plot means from the five selected plants were used from the three replicate plots for each genotype at each site to produce a standard error. Regression relationships between genotype yields in the different years were calculated across all countries. Plant height and shoot density in the third growing season were regressed with yield to assess the yield predictability using these simple growth parameters. All statistics were performed within Data Desk v.6 (Data Description, Ithaca, NY).

\section{RESULTS AND DISCUSSION}

\section{Climatic Conditions during the Growing Season}

Mean air temperatures and rainfall sums from April to September are given in Table 3 for all $3 \mathrm{yr}$ of the field trials. The long-term means ( $>10 \mathrm{yr}$ of data) and the whole year are also shown. Growing season air temperatures in 1997, 1998, and 1999 were generally warmer than normal for the five locations. Air temperatures in Portugal were at least $5^{\circ} \mathrm{C}$ higher than at the other locations.

Long-term annual rainfall at all sites was similar (626$696 \mathrm{~mm}$ ), but rainfall distribution varied markedly with location. On average, the German site had relatively wet summers $(425 \mathrm{~mm})$ while Portugal had wet winters $(509 \mathrm{~mm})$. Consequently, in Portugal, natural water availability for crop growth was very limited, and irrigation was necessary.

\section{Plant Survival}

Established Miscanthus spp. stands grow from overwintering rhizomes in spring. At the more northern sites of Denmark and Sweden, nearly $100 \%$ and $>50 \%$ of the plants of $M . \times$ giganteus and $M$. sacchariflorus, respectively, died during the first winter following planting, but losses of $M$. sinensis plants were only 1 to $16 \%$ (Table 4). In Denmark and Sweden, plant losses of $M$. sinensis hybrids (No. 6-10) varied from only $1 \%$ in Genotype no. 10 to $60 \%$ in Genotype no. 9. In these countries, winter soil temperatures in the first year following planting fell below $-4.5^{\circ} \mathrm{C}$. In England, Germany, and Portugal, where winter soil temperatures were warmer $\left(>-2.8^{\circ} \mathrm{C}\right)$, all genotypes survived. These observations

Table 4. Plant losses and minimum soil temperature recorded at $5-\mathrm{cm}$ depth in the field during the first winter (1997-1998) for the 15 Miscanthus genotypes at five sites.

\begin{tabular}{|c|c|c|c|c|c|c|c|c|c|c|c|c|c|c|c|c|}
\hline \multirow[b]{3}{*}{ Country } & \multicolumn{15}{|c|}{ Genotype group and no. } & \multirow{3}{*}{$\begin{array}{c}\text { Soil } \\
\text { temp. }\end{array}$} \\
\hline & \multicolumn{4}{|c|}{ Gig } & \multirow{2}{*}{$\frac{\text { Sac }}{5}$} & \multicolumn{5}{|c|}{ Sin-H } & \multicolumn{5}{|c|}{ Sin } & \\
\hline & 1 & 2 & 3 & 4 & & 6 & 7 & 8 & 9 & 10 & 11 & 12 & 13 & 14 & 15 & \\
\hline & & & & & & & - \% & ant & & & & & & & - & ${ }^{\circ} \mathbf{C}$ \\
\hline Sweden & 99 & 93 & 97 & 99 & 50 & 17 & 52 & 6 & 50 & 2 & 6 & 5 & 16 & 5 & 5 & -5.4 \\
\hline Denmark & 100 & 98 & 96 & 96 & 67 & 1 & 8 & 6 & 60 & 1 & 1 & 10 & 15 & 6 & 1 & -4.5 \\
\hline England & 0 & o & 0 & 0 & 2 & 0 & 0 & 1 & 1 & 0 & 4 & 1 & 21 & 1 & $\mathbf{0}$ & -1.2 \\
\hline Germany & 0 & 1 & 0 & 1 & 1 & 0 & 5 & 0 & 1 & 0 & 1 & 0 & 0 & 1 & 5 & -2.8 \\
\hline Portugal & 0 & 0 & o & 0 & 0 & 0 & o & 0 & 0 & 0 & 0 & o & 0 & 0 & $\mathbf{0}$ & NA \\
\hline
\end{tabular}


Table 5. Autumn yield for the first 3 yr $(1997,1998$, and 1999) of 15 Miscanthus genotypes grown at five locations in Europe.

\begin{tabular}{|c|c|c|c|c|c|c|c|c|c|c|c|c|c|c|c|c|c|c|c|}
\hline \multirow[b]{3}{*}{ Country } & \multirow[b]{3}{*}{ Year } & \multirow[b]{3}{*}{ Date $\dagger$} & \multicolumn{15}{|c|}{ Genotype group and no. } & \multirow[b]{3}{*}{ Mean } & \multirow{3}{*}{$\begin{array}{l}\text { Tukey } \\
\text { MSD }\end{array}$} \\
\hline & & & \multicolumn{4}{|c|}{ Gig } & \multirow{2}{*}{$\frac{\text { Sac }}{5}$} & \multicolumn{5}{|c|}{ Sin-H } & \multicolumn{5}{|c|}{ Sin } & & \\
\hline & & & 1 & 2 & 3 & 4 & & 6 & 7 & 8 & 9 & 10 & 11 & 12 & 13 & 14 & 15 & & \\
\hline & & & & & & & & & & dry I & atter $y$ & eld, $t$ & $a^{-1}$ & & & & & & \\
\hline \multirow{3}{*}{ Sweden } & 1997 & 12 Nov. & 0.1 & 0.1 & 0.1 & 0.1 & 0.5 & 0.2 & 0.4 & 0.4 & 0.6 & 0.8 & 0.4 & 0.2 & 0.2 & 0.4 & 0.3 & 0.3 & 0.6 \\
\hline & 1998 & 24 Nov. & 0.0 & 0.0 & 0.0 & 0.0 & 0.0 & 5.0 & 3.8 & 9.5 & 5.4 & 11.4 & 5.2 & 5.0 & 6.7 & 3.9 & 3.1 & 3.9 & 4.4 \\
\hline & 1999 & 18 Oct. & 0.0 & 0.0 & 0.0 & 0.0 & 0.0 & 19.3 & 11.0 & 24.7 & 14.2 & 20.5 & 15.4 & 15.3 & $\mathbf{1 7 . 3}$ & 13.8 & 9.7 & 10.7 & 8.0 \\
\hline \multirow[t]{3}{*}{ Denmark } & 1997 & 27 Nov. & 0.7 & 0.8 & 1.1 & 0.8 & 0.5 & 0.9 & 1.1 & 0.3 & 1.4 & 1.4 & 0.4 & 0.3 & 0.3 & 0.6 & 0.2 & 0.7 & 0.7 \\
\hline & 1998 & 19 Nov & 0.0 & 0.0 & 0.0 & 0.0 & 0.7 & 5.2 & 4.7 & 4.1 & 1. & 7.8 & 5. & 3.1 & 3. & 2. & 1. & 0 & 3.0 \\
\hline & 1999 & 18 Nov. & 0.0 & 0.0 & 0.0 & 0.0 & 1.4 & 16.4 & 10.4 & 15.9 & 0.9 & 18.2 & 15.0 & 12.4 & 11.2 & 9.9 & 6.8 & 7.9 & 5.1 \\
\hline \multirow[t]{3}{*}{ England } & 1997 & 15 Nov. & 0.6 & 0.8 & 0.9 & 0.8 & 0.4 & 1.4 & 1.2 & 0.2 & 1.7 & 0.8 & 0.1 & 0.1 & 0.2 & 0.1 & 0.2 & 0.6 & 0.8 \\
\hline & 1998 & 24 Nov. & 3.0 & 5.7 & 5.9 & 5.3 & 1.9 & 7.0 & 5.9 & 1.4 & 7.7 & 6.0 & 1.9 & 2.0 & 3.0 & 0.6 & 2.0 & 4.0 & 3.8 \\
\hline & 1999 & 3 Nov. & 13.8 & 16.8 & 18.7 & 14.6 & 11.1 & 15.7 & 17.7 & 6.5 & 15.8 & 14.0 & 8.0 & 7.0 & 10.9 & 4.6 & 5.9 & 12.1 & 7.4 \\
\hline \multirow{3}{*}{ Germany } & 1997 & 11 Nov. & 3.2 & 3.4 & 3.3 & 3.0 & 2.9 & 2.8 & 1.1 & 1.0 & 3.0 & 1.9 & 0.7 & 0.6 & 1.0 & 0.5 & 0.5 & 1.9 & 2.0 \\
\hline & 1998 & 23 Nov & 8.0 & 8.7 & 8.9 & 8.1 & 4.6 & 7.4 & 3.6 & 7.3 & 7.6 & 9.7 & 4.4 & 4.5 & 5.0 & 3.6 & 2.5 & 6.2 & 5.2 \\
\hline & 1999 & 21 Nov. & 22.8 & 24.3 & 25.7 & 29.1 & 12.6 & 20.0 & 17.0 & 19.2 & 10.3 & 19.1 & 12.8 & 10.9 & 12.3 & 10.4 & 9.1 & 17.0 & 15.3 \\
\hline \multirow{3}{*}{ Portugal } & 1997 & 27 Oct. & 8.4 & 4.6 & 6.0 & 8.1 & 4.4 & 7.9 & 7.5 & 2.5 & 7.6 & 6.3 & 5.9 & 4.7 & 5.7 & 5.3 & 2.0 & 5.8 & 2.7 \\
\hline & 1998 & 15 Oct. & 26.9 & 25.5 & 30.3 & 25.6 & 15.1 & 18.4 & 27.2 & 10.8 & 20.1 & 13.6 & 10.6 & 10.2 & 16.3 & 11.6 & 8.8 & 18.1 & 8.5 \\
\hline & 1999 & 6 Oct. & 37.8 & 36.4 & 36.8 & 34.7 & 35.2 & 27.2 & 40.9 & 21.0 & 26.3 & 20.3 & 16.2 & 16.3 & 22.4 & 16.1 & 16.1 & 26.9 & 17.1 \\
\hline
\end{tabular}

\begin{tabular}{lrr} 
Source of variation & df & $\boldsymbol{P}$ \\
Country & $\mathbf{4}$ & $* * *$ \\
Genotype & $\mathbf{1 4}$ & $* * *$ \\
Country $\times$ genotype & $\mathbf{5 6}$ & $* * *$ \\
Year & $\mathbf{2}$ & $* * *$ \\
Country $\times$ year & $\mathbf{8}$ & $* * *$ \\
Genotype $\times$ year & $\mathbf{2 8}$ & $* * *$ \\
Country $\times$ genotype $\times$ year & $\mathbf{9 2}$ & $* * *$ \\
\hline
\end{tabular}

$* * *$ Significant at the 0.001 probability level. ANOVA's on the three years within each site showed genotype, year, and genotype $\times$ year differences were all highly significant (***) (not shown above).

$\dagger$ Harvest date.

$\$$ Minimum significant differences (MSD) between genotypes within a site and within a year were calculated by the Tukey test at $P=0.05$.

are consistent with artificial freezing tests, which showed that rhizomes of $M$. sinensis hybrids could survive temperatures below $-4.5^{\circ} \mathrm{C}$, but rhizomes of $M . \times$ giganteus and $M$. sacchariflorus are killed at approximately $-3^{\circ} \mathrm{C}$ (Clifton-Brown and Lewandowski, 2000). It appears, therefore, that temperatures in Sweden and Denmark were too cold for $M$. $\times$ giganteus and $M$. sacchariflorus. Consequently, $M$. sinensis and $M$. sinensis hybrids can be recommended for the regions where soil temperatures at $5-\mathrm{cm}$ depth are likely to fall below $-3^{\circ} \mathrm{C}$.

\section{Biomass Yield}

Following planting in 1997, average biomass yield for all genotypes across all sites was only $1.9 \mathrm{t} \mathrm{ha}^{-1}$ in autumn (Table 5). Highest mean yields were in Portugal $\left(5.8 \mathrm{tha}^{-1}\right)$ while lowest yields were in Sweden $(0.36 \mathrm{t}$ $\left.\mathrm{ha}^{-1}\right)$. There were several reasons for this. First, late frosts in Sweden prevented planting before June, thus shortening the growing season by 2 mo compared with Portugal. Second, the plants were irrigated in Portugal, but in Sweden, growth was probably water limited because rainfall was abnormally low (Table 3 ). Third, growth temperatures in Portugal were higher throughout the season, promoting faster establishment.

In the second year, average yield for all sites and all surviving genotypes increased to $8.6 \mathrm{t} \mathrm{ha}^{-1}$. In Portugal, $M . \times$ giganteus yields averaged $27 \mathrm{t} \mathrm{ha}^{-1}$, but in England and Germany, where average air temperatures were approximately $5^{\circ} \mathrm{C}$ lower and plants were not irrigated, yields did not exceed $9 \mathrm{t} \mathrm{ha}^{-1}$. M. sinensis hybrid no. 10 outyielded all other genotypes in Sweden and Denmark (11.4 and $7.8 \mathrm{t} \mathrm{ha}^{-1}$, respectively). This indicates that M. sinensis hybrid no. 10 is better suited to low winter soil temperatures and shorter growing seasons than other genotypes in these trials.

In the third year, the highest-yielding genotypes in Germany and England were of $M . \times$ giganteus. In Portugal, the highest yield was obtained from $M$. sinensis hybrid no. 7, with autumn yield of $40.9 \mathrm{t} \mathrm{ha}^{-1}$. M. sinensis genotypes (No. 11-15) produced a consistently lower yield than the highest-yielding genotype at any given location. Interestingly, at the higher latitudes in Sweden and Denmark, the yield gap between the $M$. sinensis genotype group (No. 11-15) and the other genotypes was smaller than at lower latitudes. This can be explained through lower overall yields at higher latitudes due to the shorter growing season.

Biomass yield interactions between year and genotype in any given country were significant at $P<0.001$. Interactions among country, year, and genotype were also significant at $P<0.001$. This shows that stand maturity increases yield significantly for all surviving genotypes. Equally, the different environmental conditions, particularly climate and soil, influence genotype yield performance (Table 5).

Comparisons between yields obtained in these field trials and other trials in Europe can only be made for the widely grown $M . \times$ giganteus. Trials in northern regions tend to mature slower than at southern latitudes, and ceiling yields of $15 \mathrm{tha}^{-1}$ are reached after only the fourth or fifth year (Lewandowski et al., 2000). Yields 
Table 6. Correlations between yields in the first, second, and third growing seasons and the shoot densities and plant height using data from all sites and all genotypes except for those that died in Sweden and Denmark during the first winter following planting.

\begin{tabular}{llccccccc}
\hline Variable 1 & \multicolumn{1}{c}{ Variable 2 } & df & Slope & $\boldsymbol{P}$ & Constant & $\boldsymbol{P}$ & $\boldsymbol{b}^{2}$ \\
\hline Yield year 1 & Yield year 3 & $\mathbf{6 4}$ & $\mathbf{2 . 9}$ & $* * *$ & $\mathbf{1 1 . 0}$ & $* * *$ & $\mathbf{0 . 5 6}$ \\
Yield year 2 & Yield year 3 & $\mathbf{6 4}$ & $\mathbf{1 . 2}$ & $* * *$ & $\mathbf{8 . 0}$ & $* * *$ & $\mathbf{0 . 8 1}$ \\
Yield year 3 & Shoot density year 3 & $\mathbf{6 4}$ & $\mathbf{0 . 0}$ & NS & $\mathbf{1 4 . 8}$ & $* * *$ & $\mathbf{0 . 0 7}$ \\
Yield year 3 & Height year 3 & $\mathbf{6 4}$ & $\mathbf{0 . 1}$ & $* * *$ & $-\mathbf{4 . 5}$ & NS & $\mathbf{0 . 5 4}$ \\
\hline
\end{tabular}

**** Significant at the 0.001 probability level.

$\dagger$ NS, not significant at $P<0.05$.

with irrigation in excess of $25 \mathrm{tha}^{-1}$ in southern Europe are often achieved in the second year with $M . \times$ giganteus (Clifton-Brown et al., 2001). Therefore, in warm climates, yields after the second growing season are a good indication of the potential ceiling yield from a genotype, but in cooler climates, it takes at least $3 \mathrm{yr}$ to reach a ceiling. As expected, regression coefficients with third-year yield against first- and second-year yields were better for the second year than for the first year (Table 6).

\section{Growing Season Performance Characteristics}

The greatest yield variance from site to site was observed in the M. sinensis hybrid genotypes. For example, the lowest autumn yields in Sweden were for Genotype no. 7, the genotype that performed best in Portugal and England. For future breeding of higher yielding Miscanthus genotypes better suited to specific environments, it will be necessary to identify key growth characteristics that will increase the quantity of radiation intercepted and its conversion into harvestable dry matter over a growing season. Recent evidence suggests that photosynthetic efficiency per unit area of leaf has not been successful in identifying more productive genotypes of crop plants (Lawlor, 1995). Furthermore, within a photosynthetic group, radiation conversion efficiency varies little (Monteith, 1978). Thus, yield from a given genotype will depend largely on the efficiency with which radiation is intercepted by the canopy leaves. This efficiency is dependent on a range of characteristics, including shoot emergence time from the overwintering rhizome and rate of canopy closure [a function of shoot density and leaf expansion rate (Clifton-Brown and Jones, 1997), flowering time after which growth stops and senescence begins]. These characteristics are detailed here for the third year following planting.

Genotypic differences in shoot emergence time in the spring were not observed within these field trials. Evidently, monthly measurements of plant height were insufficient to identify emergence differences at a site (data not shown). However, the monthly measurements did show the earlier start to the growing season in Portugal (data not shown). By the end of the third growing season, plants were tallest in Portugal $(223 \mathrm{~cm})$ and shortest in Denmark $(120 \mathrm{~cm})$ (Table 7).

Analysis of variance showed that shoot density and plant height differed significantly for all 15 genotypes within and between countries $(P>0.001)$ at the end of the growing season (Table 7). In those countries where $M$. $\times$ giganteus and $M$. sacchariflorus survived the first winter, plants were generally taller than the $M$. sinensis and $M$. sinensis hybrids. In contrast, shoot densities were higher in the $M$. sinensis and $M$. sinensis hybrids. Evidently, there is an antagonistic relationship between plant height and shoot density.

Genotypic variation in plant height appears to be associated with flowering time. The tallest genotypes at a site (e.g., M. sacchariflorus or $M . \times$ giganteus) tended to flower later than the earliest-flowering $M$. sinensis genotypes (No. 11-15). Indeed, it was only in Portugal where all of the genotypes reached flowering before autumn (Table 8). Thermal time required from emergence in spring to flowering of $M$. $\times$ giganteus in Portu-

Table 7. Shoot density and plant height at the end of the growing season for 15 Miscanthus genotypes grown at five locations in Europe.

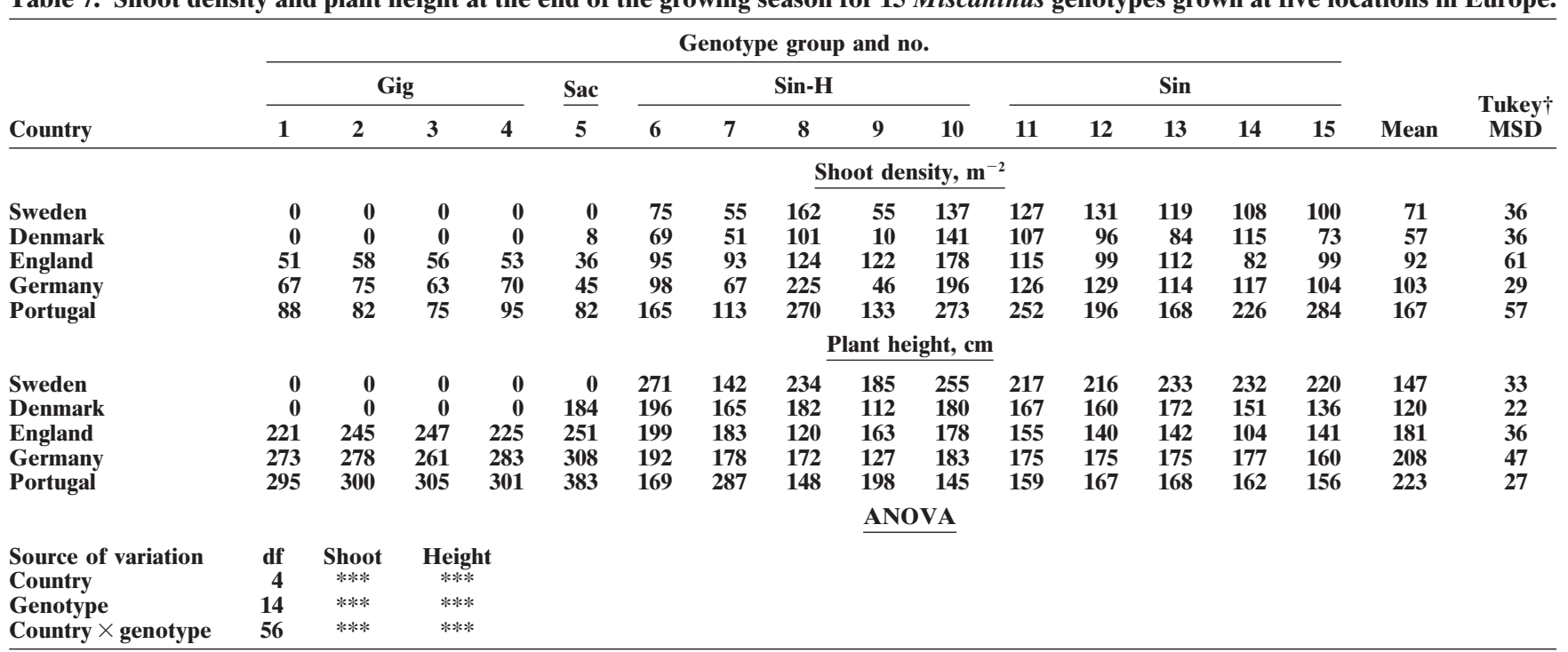


Table 8. Flowering date and shoot greenness (\%) in autumn at the end of the third growing season (1999) for 15 Miscanthus genotypes grown at five locations in Europe.

\begin{tabular}{|c|c|c|c|c|c|c|c|c|c|c|c|c|c|c|c|}
\hline \multirow[b]{3}{*}{ Country } & \multicolumn{15}{|c|}{ Genotype group and no. } \\
\hline & \multicolumn{4}{|c|}{ Gig } & \multirow{2}{*}{$\frac{\text { Sac }}{5}$} & \multicolumn{5}{|c|}{ Sin-H } & \multicolumn{5}{|c|}{ Sin } \\
\hline & 1 & 2 & 3 & 4 & & 6 & 7 & 8 & 9 & 10 & 11 & 12 & 13 & 14 & 15 \\
\hline & \multicolumn{15}{|c|}{ Flowering date } \\
\hline $\begin{array}{l}\text { Sweden } \\
\text { Denmark } \\
\text { England } \\
\text { Germany } \\
\text { Portugal }\end{array}$ & $\begin{array}{c}\dagger \\
\dagger \\
\text { none } \\
\text { none } \\
\text { 10 Sept. }\end{array}$ & $\begin{array}{c}\dagger \\
\dagger \\
\text { none } \\
\text { none } \\
\text { 13 Sept. }\end{array}$ & $\begin{array}{c}\dagger \\
\dagger \\
\text { none } \\
\text { none } \\
\text { 10 Sept. }\end{array}$ & $\begin{array}{c}\dagger \\
\dagger \\
\text { none } \\
\text { none } \\
\text { 10 Sept. }\end{array}$ & $\begin{array}{c}\dagger \\
\dagger \\
\text { none } \\
\text { none } \\
\text { 16 Sept. }\end{array}$ & $\begin{array}{r}8 \text { Sept. } \\
15 \text { Sept. } \\
29 \text { Sept. } \\
26 \text { Aug. } \\
6 \text { July }\end{array}$ & $\begin{array}{l}\text { none } \\
\text { none } \\
\text { none } \\
\text { 20 Sept. } \\
10 \text { Aug. }\end{array}$ & $\begin{array}{l}\text { none } \\
15 \text { Oct. } \\
29 \text { Sept. } \\
20 \text { Sept. } \\
6 \text { July }\end{array}$ & $\begin{array}{l}20 \text { Sept. } \\
15 \text { Oct. } \\
29 \text { Sept. } \\
20 \text { Sept. } \\
19 \text { July }\end{array}$ & $\begin{array}{l}8 \text { Sept. } \\
15 \text { Sept. } \\
29 \text { Sept. } \\
12 \text { Aug. } \\
22 \text { June }\end{array}$ & $\begin{array}{l}10 \text { Aug. } \\
20 \text { Aug. } \\
22 \text { July } \\
13 \text { July } \\
8 \text { June }\end{array}$ & $\begin{array}{l}10 \text { Aug. } \\
20 \text { Aug. } \\
22 \text { July } \\
30 \text { June } \\
8 \text { June }\end{array}$ & $\begin{array}{l}20 \text { Aug. } \\
25 \text { Aug. } \\
22 \text { July } \\
13 \text { July } \\
15 \text { June }\end{array}$ & $\begin{array}{l}2 \text { Aug. } \\
20 \text { July } \\
22 \text { July } \\
30 \text { June } \\
4 \text { June }\end{array}$ & $\begin{array}{l}25 \text { July } \\
20 \text { July } \\
22 \text { July } \\
30 \text { June } \\
4 \text { June }\end{array}$ \\
\hline & \multicolumn{15}{|c|}{ Greenness $(\%)$} \\
\hline Sweden & $\dagger$ & $\dagger$ & $\dagger$ & $\dagger$ & $\dagger$ & 0 & $46 \pm 3$ & $2 \pm 2$ & $15 \pm 15$ & $2 \pm 2$ & 0 & 0 & 0 & 0 & 0 \\
\hline Denmark & $\dagger$ & $\dagger$ & $\dagger$ & $\dagger$ & $24 \pm 7$ & $8 \pm 4$ & $39 \pm 2$ & 0 & $60 \pm 1$ & 0 & 0 & 0 & 0 & 0 & 0 \\
\hline England & $\mathbf{2 5} \pm \mathbf{1 6}$ & o & $16 \pm 11$ & 0 & $24 \pm 4$ & 0 & & 0 & $72 \pm 2$ & 0 & 0 & 0 & 0 & 0 & 0 \\
\hline Germany & $17 \pm 3$ & $20 \pm 0$ & $15 \pm 3$ & $22 \pm 7$ & $15 \pm 3$ & $15 \pm 3$ & $62 \pm 2$ & 0 & $44 \pm 4$ & $2 \pm 1$ & 0 & $4 \pm 2$ & $22 \pm 10$ & 0 & 0 \\
\hline Portugal & $\mathbf{5 3} \pm \mathbf{3}$ & $51 \pm 2$ & $49 \pm 1$ & $45 \pm 2$ & $40 \pm 4$ & $44 \pm 2$ & $60 \pm 4$ & $24 \pm 6$ & $56 \pm 6$ & $37 \pm 3$ & $43 \pm 7$ & $48 \pm 2$ & $42 \pm 12$ & $45 \pm 5$ & $48 \pm 2$ \\
\hline
\end{tabular}

$\dagger$ Indicates plants did not survive the first winter following planting.

+ Means shown are \pm 1 SE, $n=3$, except Portugal where $n=2$.

gal was $>1800$ degree days above a threshold of $10^{\circ} \mathrm{C}$. In contrast, the M. sinensis genotypes (No. 11-15) only needed 400 to 600 degree days in Portugal. This effectively halves the length of the available growing season, approximately halving the yield (Tables 5 and 8). In Sweden and Denmark, where temperatures are lower, $M$. sinensis flowers later in the growing season so that less radiation is lost than at warmer sites. As with yield (Table 5), flowering time was most variable for the $M$. sinensis hybrid (No. 6-10) group within a site. For example, in Portugal, Genotype no. 7 was late flowering, and this coincided with the highest yield recorded throughout (Table 5).

In general, late flowering was associated with late senescence. For example, Genotype no. 7 senesced latest at all sites and was still relatively green compared with all other genotypes except Genotype no. 9 in late autumn (Table 8). Although early flowering leads to nearly complete senescence in northern climates, it did not lead to low greenness in Portugal. The M. sinensis hybrid genotypes no. 7 and 9 are stay-green types. Such stay-green traits are being investigated in other crops (Thomas and Howarth, 2000; Xu et al., 2000) with a view to increasing yield. However, in northern regions of Europe, the late-senescing genotypes ( $M$. sinensis hybrids no. 7 and 9) yielded badly. Autumn frosts kill the green leaves of late-maturing genotypes at northern sites. This may lead to insufficient relocation of nutrients and assimilates from the aboveground shoots to the rhizomes in autumn, reducing both the overwintering capacity and regrowth potential in the following spring (Pude et al., 1997). Interestingly, overwintering of Genotypes no. 7 and 9 in Sweden and Denmark were the poorest of the M. sinensis hybrids (Table 4).

When genotypes that failed to overwinter in Sweden and Denmark are omitted (Table 4), plant height was the growing season performance characteristic most highly correlated with yield (Table 6). Greater height implies later flowering, and therefore, longer periods for which radiation is converted to biomass. Shoot densities were not found to be significantly related to yield (Table
6) for the genotypes tested. Exceptions to these general relationships included $M$. sacchariflorus (No. 5), which despite being the tallest genotype, had a low shoot density that lowered its yields below the highest-yielding genotypes (Table 7). M. sinensis hybrid genotypes (No. 6-10) showed the potential for breeding genotypes with appropriate characteristics for a wide range of environmental conditions. For future breeding, M. sacchariflorus will be an invaluable parent to create new taller, and therefore, higher yielding $M$. sinensis hybrid genotypes with rhizome freezing tolerance and late flowering time.

\section{Practical Issues in Relation to Miscanthus spp. Production for Biomass}

Without irrigation, Miscanthus spp. would not be productive in Portugal because of the combination of a low water-retentive sandy soil type, high evaporative demand, and low rainfall during the growing season. At the other four sites, no irrigation was used in 1999. Yields were highest at the German site, which had not only the most rainfall in 1999, but also a heavy clay soil. Because biomass production must be low cost and low input, it is unlikely that irrigation will be economic, and a combination of site and genotype selection will be important to ensure survival and adequate yields.

It is important to point out that biomass quality for combustion improves if the crop is harvested in early spring rather than in the previous autumn. Yields can, however, be as much as $30 \%$ less in the following spring due to death and detachment of leaves and stem tops (Clifton-Brown et al., 2000; Jørgensen, 1997).

There is a potential weed risk from the diploid Miscanthus genotypes in Europe because fertile seeds were produced at all sites where flowering occurred. To date, seedlings have not been found to spread far from the plots, which have had frequently mown paths. Current breeding programs for Miscanthus spp. are attempting to produce infertile hybrids (K.K. Petersen, personal communication, 2000). 


\section{CONCLUSIONS}

New plantations with $M . \times$ giganteus and $M$. sacchariflorus are unlikely to be viable where winter soil temperatures fall below $-3^{\circ} \mathrm{C}$ at a depth of $5 \mathrm{~cm}$. In England and Germany, $M . \times$ giganteus genotypes were among the top performers. These genotypes yielded well in Portugal, $>34 \mathrm{t} \mathrm{ha}^{-1}$, but the highest-yielding genotype in Portugal was the stay-green M. sinensis hybrid no. 7 (41 $\mathrm{t} \mathrm{ha}^{-1}$ dry matter). The highest-yielding genotypes in Sweden and Denmark were the M. sinensis hybrids no. 6,8 , and 10 . These results demonstrate that different $M$. sinensis hybrids can be found for a wide range of climatic conditions in Europe. In mid-Europe, $M . \times$ giganteus is still the genotype of preference. Plant height, which is largely controlled by flowering time, was a more important selection characteristic than shoot density.

\section{ACKNOWLEDGMENTS}

The authors thank Sabine Schneider, Birgit Beierl, and the team at the Ihinger Hof field station for technical assistance in the field in Germany. Kaj Eskesen is thanked for technical assistance in the field in Denmark. Michael Sommer and Søren B. Torp are thanked for their work on the soil taxonomy. Thanks also to Mike Jones for reading the manuscript. The EMI project was funded by EU contract FAIR3 CT-96-1392.

\section{REFERENCES}

Christian, D.G. 1994. Quantifying the yield of perennial grasses grown as a biofuel for energy generation. Renewable Energy 5:762-766.

Clifton-Brown, J.C., and M.B. Jones. 1997. The thermal response of leaf extension rate in genotypes of the C4-grass Miscanthus: An important factor in determining the potential productivity of different genotypes. J. Exp. Bot. 48:1573-1581.

Clifton-Brown, J.C., and I. Lewandowski. 2000. Overwintering problems of newly established Miscanthus plantations can be overcome by identifying genotypes with improved rhizome cold tolerance. New Phytol. 148:287-294.

Clifton-Brown, J.C., S.P. Long, and U. Jørgensen. 2001. Miscanthus productivity. p. 46-67. In M.B. Jones and M. Walsh (ed.) Miscanthus-for energy and fibre. James and James (Science Publishers), London (in press).
Clifton-Brown, J.C., B.M. Neilson, I. Lewandowski, and M.B. Jones. 2000. The modelled productivity of Miscanthus $\times$ giganteus (GREEF et DEU) in Ireland. Ind. Crops Prod. 12:97-109.

Greef, J.M., and M. Deuter. 1993. Syntaxonomy of Miscanthus $\times$ giganteus GREEF et DEU. Angew. Bot. 67:87-90.

Greef, J.M., M. Deuter, C. Jung, and J. Schondelmaier. 1997. Genetic diversity of European Miscanthus species revealed by AFLP fingerprinting. Genet. Resources and Crop Evolution 44:185-195.

Hodkinson, T.R., S.A. Renvoize, and M.W. Chase. 1997. Systematics in Miscanthus. Aspects Appl. Biol. 49:189-198.

Jones, M.B., and M. Walsh. 2001. Miscanthus-for energy and fibre. James and James (Science Publishers), London (in press).

Jørgensen, U. 1997. Genotypic variation in dry matter accumulation and content of $\mathrm{N}, \mathrm{K}$, and $\mathrm{Cl}$ in Miscanthus in Denmark. Biomass Bioenergy 12:155-169.

Lawlor, D.W. 1995. Photosynthesis, productivity, and environment J. Exp. Bot. 46:1449-1461

Lewandowski, I., J.C. Clifton-Brown, J.M.O. Scurlock, and W. Huisman. 2000. Miscanthus: European experience with a novel energy crop. Biomass Bioenergy 19:209-277.

Linde-Laursen, I.B. 1993. Cytogenetic analysis of Miscanthus 'Giganteus', an interspecific hybrid. Hereditas 119:297-300.

Matumura, M., T. Hasegawa, and Y. Saijoh. 1985. Ecological aspects of Miscanthus sinensis var. condensatus, $M . \times$ sacchariflorus, and their $3 \times$-, $4 \times$-hybrids: I. Process of vegetative spread. Res. Bull. Fac. Agric., Gifu Univ. 50:423-433.

Monteith, J.L. 1978. Reassessment of the maximum growth rates for C3 and C4 crops. Exp. Agric. 14:1-5.

Nielsen, P.N. 1987. The productivity of Miscanthus sinensis 'Giganteus' on different soil types. Tidsskr. Planteavl. 91:275-281.

Potter, L., M.J. Bingham, M.G. Baker, and S.P. Long. 1995. The potential of two perennial $\mathrm{C} 4$ grasses and a perennial $\mathrm{C} 4$ sedge as ligno-cellulosic fuel crops in N.W. Europe. Crop establishment and yields in E. England. Ann. Bot. (London) 76:513-520.

Pude, R., H. Franken, W. Diepenbrock, and J.M. Greef. 1997. Ursachen der Auswinterung von einjährigen Miscanthus-Beständen. Pflanzenbauwissenchaften 1:171-176.

Schwarz, H.U., D.P.L. Murphy, and E. Schnug. 1994. Studies of the growth and yield of $M . \times$ giganteus in Germany. Aspects Appl. Biol. 40:533-540.

Soil Survey Staff. 1999. Soil taxonomy-a basic system of soil classification for making and interpreting soil surveys. 2nd ed. USDANRCS Agric. Handb. 436. U.S. Gov. Print. Office, Washington, DC.

Thomas, H., and C.J. Howarth. 2000. Five ways to stay green. J. Exp. Bot. 51:329-337.

Xu, W.W., P.K. Subudhi, O.R. Crasta, D.T. Rosenow, J.E. Mullet, and H.T. Nguyen. 2000. Molecular mapping of QTLs conferring stay-green in grain sorghum (Sorghum bicolor L. Moench). Genome 43:461-469. 